\title{
公路工程路基路面压实施工技术措施分析
}

陈念东

桂林市兴安县交通运输局

DOI:10.18686/bd.v2i4.1312

[摘要] 近几年, 国民经济增长迅速, 有效提升了人们的生活水平, 在一定程度上增加了汽车的使用率。而公路工程是确保 民众出行安全的重要条件,其路面工程的施工质量会对整个公路工程的安全性及稳定性造成巨大的影响,其中路基路面部 分的压实施工更是确保工程质量的关键, 如果不能对压实施工技术进行有效的应用, 非常容易在压实施工中埋下质量隐患, 导致公路的路基路面出现各种各样的问题,影响工程的总体质量,甚至影响公路的使用安全,基于此,文章围绕公路路基路面 部分的压实施工技术进行讨论, 了解影响该项技术效果的因素,并对其进行具体的探讨。

[关键词] 公路工程; 路基路面; 压实施工; 技术措施

经济建设的发展对公路建设事业的发展产生了很大的 推动作用,大大提升了公路工程的建设数量,使人们的交通 条件得到了很大的改善, 而为了确保公路工程的效用能够 得到有效的发挥,在确保安全运行的基础上,满足人们的出 行需要, 还需要对此类工程的施工质量进行有效的提升, 但 在具体施工中,路基路面部分的压实施工质量,与工程的整 体质量密切相关,所以, 在具体施工时, 需要对该部分的施工 进行严格的控制，进而达到提升工程施工质量的目的。而这 对于公路建设事业的快速发展具有非常积极的作用。

\section{1 公路工程路基路面压实施工技术中的影响因素}

1.1 碾压施工技术影响

在路基路面部分的压实施工中, 碾压施工是工作流程 中最为重要的环节之一, 其中的技术应用涉及到碾压的速 度、厚度以及遍数等, 在实际施工过程中, 由于施工方案设置 不同, 在碾压施工技术方面的要求也会存在一定的差异,而 且相关技术规范对碾压施工技术的应用同样具有一定的约 束性, 要求在进行碾压施工时, 施工人员要严格按照施工规 定完成各项技术操作, 以先慢压后快压、先轻压后重压以及 先边缘后中间等要求为基准实施操作, 使碾压施工的质量 能够达到工程设计的标准。此外, 碾压速度同样会对工程质 量造成较大的影响, 在进行碾压施工期间,如果操作速度太 快, 混合料当中的空气难以被充分压出, 容易使路面产生波 形起伏的问题,而如果碾压速度控制过慢,在对某些施工材 料进行施工时, 容易造成过大的重力荷载, 进而影响工程质 量。

1.2 含水量对技术应用的影响

在公路工程施工过程中, 含水量是一项重要的施工参 数, 施工环境中的含水率会对施工技术方案的实施造成直 接的影响, 含水量在土壤地层的地质系数当中属于较为重 要的内容,随着压实施工的推进, 在土层方面的压实密度会 逐渐提升, 会有效增强路基土质当中的土壤粘合力以及内 部摩擦力, 而土壤当中的水分会对内部摩擦产生阻力, 在压 实达到相应程度时, 压实施工产生的作用系数对于土层抗
力的作用会越来越小,这时会视为压实质量达到要求,但如 果土壤当中存在含水量过高的问题, 会使土壤摩擦力被减 小,形成润滑效用,而作用在土壤当中的压实效用将会减小, 从而加大土壤干容重。因此,全标纸当中的水实曲线会产生 驼峰状况, 在施工材料为细颗粒土、天然砾石、级配砾石、级 配碎石以及石灰等不同条件下, 需要结合实际含水量, 对压 实技术予以实施, 确保最佳的干容重效果, 以此来提升压实 施工的质量。

\section{3 压实机械影响}

在对路基进行压实处理的过程中, 对压实施工设备进 行正确的选择具有非常重要的意义, 压实设备自身的性能 和吨位参数对工程质量具有决定性的作用, 如果施工过程 中应用的压实设备吨位较大, 能够使压实质量得到很大的 提升, 而如果选用的设备吨位较小, 容易出现路面压实不到 位,影响路面稳固性的问题。

\section{2 公路工程中的路基路面压实施工技术}

2.1 压实准备工作

工程施工人员要在正式进行压实施工之前, 将路基路 面当中的各项工作处理好, 在工程当中, 各环节施工与整个 工程的进展情况息息相关, 其中基底处理更是重中之重,涉 及到基底的换填和加固桩处理等内容, 在对路基实施填筑 以前, 要求施工人员结合现场情况, 针对施工方案加强研究 和分析, 对其中可能产生的问题加以注意, 并制定相应的解 决对策, 避免其中存在问题隐患, 影响压实施工技术的正常 应用"

在填筑施工之前, 施工人员还要针对路基填料做好含 水率检验工作, 确保填料含水量能够达到工程施工标准, 如 果发现路基填料当中存在含水率过大的问题, 应该采用相 应的除湿方法进行处理。一般会对物理方法进行应用,例如, 采用翻挖晾晒的方法对路基填料进行处理,当然,也可以对 化学处理方式进行应用,例如, 将适量的填充剂加人到路基 填料当中,包括生石灰等,使其能够与填料之间产生化学反 应,使其中的水分被减少; 如果路基填料当中的含水量比较 
低,可以对酒水的方式进行应用,使填料本身的含水量得到 提升, 以此来满足施工标准的要求 ${ }^{[2]}$

2.2 路基部分的压实施工技术

对于公路工程中的路基压实施工来说, 其压实效果往 往会受到实际压实度的影响, 为了对路基部分的压实施工 质量进行有效的控制, 需要施工人员做好材料含水量控制, 使土壤密实度得到改善, 进而达到提升路基压实效果的目 的,使其压实度得到保障,达到提升路基稳定性、加强行车安 全性的效果,因此,在对公路路基进行压实施工时,还要掌握 路基压实所需的土质条件、填料种类以及施工规模等要素, 通过施工技术的合理应用,确保工程的顺利完成 ${ }^{[3]}$ 。

除此之外, 在对公路路基路面进行压实处理的过程中, 还要对路基结构层是否均匀保持重视, 确保路基部分的压 实度能够达到工程的设计标准,通常情况下,如果路基结构 的土质不同,那么其均匀性也会存在一定的差异。例如,粉质 土受水流冲刷作用影响较大, 如果路基结构层由粉质土构 成, 就很难确保路基的板体性,因此,在具体施工的过程中,施 工企业应该对所在区域的水文地质条件进行充分的勘查, 通过有效措施对地表水以及地下水进行有效的隔离, 是路 基路面部分的结构层能够具有良好的均匀性, 以此来确保 路基部分的压实质量。

2.3 路面部分的压实施工技术

要对压实长度以及速度进行有效的协调, 由于在对路 面进行铺设的过程中, 风速以及温度都是非常重要的影响 因素,如果施工期间铺设温度计较高且环境风速较小, 可以 适当延长压实作业的长度, 而如果路面材料铺设温度较低 且环境风速较大, 一定要做好压实长度和速度的有效控制, 严禁压实长度或速度设置过高,影响压实效果。

在对公路路面进行施工时, 通常会采用 2-3 台胶轮压 路机和钢轨压路机共同进行施工,其施工过程如下:第一,选 用钢轮压路机负责一次初压, 紧随推铺机进行施工, 一般需 要将初压次数控制在 2-6 次左右, 然后实施复压操作, 在复 压期间,压实工作共需要进行 6-8 次,需要保证 2-3 次静压,
而终压的碾压次数则应该控制在 1-2 次; 第二,在对公路路 面进行压实处理期间,一定保匀速进行操作, 要将由高到低 作为压实操作的基本原则; 第三,在施期间要确保压路机工 作连续性,中途不得出现突然停顿或转弯的现象 ${ }^{[4]}$ 。

\section{4 对压实设备进行合理的选择}

压式设备对路基路面施工质量具有很大的影响, 因此, 在施工过程中, 需要结合施工情况对压式设备进行合理的 选择, 以此来保证设备效用的充分发挥,进而达到提升压实 效果的目的,在对压实设备进行具体选择时,要做到以下几 点, 第一, 要对压实设备的特点及型号加以掌握, 并对其压实 强度和长度进行全面的分析, 确保设备性能可以满足工程 需要; 第二,要综合考虑设备的运行条件,确保压实设备的性 能可以得到充分的发挥, 避免在施工过程中由于施工条件 恶劣对设备的运行造成影响, 进而影响到工程的施工质量 [5]。

\section{3 结语}

综上所述,对于公路工程而言,其路基路面的施工质量 往往会受到压实施工的影响, 相关人员在对此类工程进行 具体施工的过程中, 一定要全面掌握相关的压实施工技术 并明确影响技术应用的各项因素，通过对相关技术措施的 有效应用,不断提升公路路基路面的压实质量,使公路工程 的整体质量得到全面的提升。

\section{参考文献:}

[1] 刘文龙. 提高公路路面压实施工技术质量的措施 [J].四川建材,2018,44(03):88-89+92.

[2] 杨虹. 公路工程路基路面压实施工技术措施探讨 [J].四川水泥,2017,(12):19.

[3]毕妹影.公路工程路基路面压实施工技术措施探讨 [J].建材与装饰,2018,(03):282.

[4] 徐都洋浅谈公路工程路基路面压实施工技术措施 [J].中国设备工程,2018,(01):181-182.

[5]唐必循,林宇航。公路工程路基路面压实施工技术措 施探析[J].建筑工程技术与设计,2017,6(33):937-937. 